\title{
Differentiated Instruction Training For Prospective Teachers: An Approach to Improving Reading in the Primary Classroom
}

\author{
Yvonne J. John \\ Centre for Education Programmes The \\ University of Trinidad and Tobago \\ SWWTU Circular \\ Valsayn South, Valsayn, Trinidad, and \\ Tobago
}

\author{
Stephen Joseph \\ Centre for Education Programmes \\ The University of Trinidad and \\ Tobago
}

\begin{abstract}
Many children in schools of Trinidad and Tobago are not developing the reading skills needed to achieve basic literacy. This study examined the effect of differentiated reading instruction training on prospective teachers' ability to meet the needs of students. Thirty-one prospective teachers placed in primary schools of Trinidad and Tobago participated in a two-week, field-teaching practice focusing on reading comprehension. The study used a convergent, mixed-method, research design aimed at triangulating a single group pretest/posttest quasi-experiment with survey responses, and reflections from the sample group of prospective teachers. Findings of the study revealed that the ability of prospective teachers to meet students' needs in reading greatly improved with differentiated instruction training in alternative reading structures [20].
\end{abstract}

\section{Introduction}

Reading is essential to everything that children learn in school. Creating a classroom population of eager and ready-to-read students presents teachers with an abundance of challenges and choices. The purpose for conducting this study stemmed from specific weaknesses analyzed in student outcomes based on the Trinidad and Tobago Primary School National Test, and observations of classroom practices during practicum sessions. The National Test is a standardized test administered annually in Trinidad and Tobago. Students in Standard-One and Standard-Three, are tested in English Language, Arts, and Mathematics, while those in Standard-Two and Standard-Four are tested in Science and Social Studies. The objectives of this examination are:(1) gathering information which enables administrators at the school, district and national levels to make decisions, (2) identifying areas of the primary school system that require further investigation, (3) identifying national norms, (4) comparing students' performance by school and educational districts and (5) tracking students' progress through school). The 2013 National Test Report reveals that Standard One students in 212 of 537 primary schools (40\%) are not meeting benchmarks in reading comprehension (see Table 1) [20]. 


\begin{tabular}{lll}
$\begin{array}{l}\text { Table 1: Schools } \\
\text { Comprehension Performance }\end{array}$ & $\begin{array}{c}\text { Data } \\
\text { Test 2013 }\end{array}$ & $\begin{array}{l}\text { Reading } \\
\text { inational }\end{array}$ \\
\hline Status & $\begin{array}{l}\text { No.of } \\
\text { Schools }\end{array}$ & $\begin{array}{l}\% \\
\text { Primary } \\
\text { schools }\end{array}$ \\
\hline $\begin{array}{l}\text { Failing }=\text { Percent of } \\
\text { students not meeting }\end{array}$ & $39.5 \%$ \\
benchmarks (<50\%) \\
$\begin{array}{l}\text { Passing = Percent of } \\
\text { students meeting }\end{array}$ \\
$\begin{array}{l}\text { benchmarks }(\geq 50 \%) \\
\text { Total }\end{array}$ & $60.5 \%$ \\
\hline
\end{tabular}

Closer observation of instruction in schools revealed that both in-service and pre-service teachers continue to give whole group instruction in reading with little or no differentiated instruction provided, particularly for the at-risk students. Overall, the statistics show that students in some primary and special schools of Trinidad and Tobago continue to fail in basic areas of reading such as vocabulary and comprehension [20]. In response to the student data and observation of methods employed by teachers, a decision was taken to conduct a study with teacher-trainees in special needs education, using differentiated reading instruction.

\section{Literature Review}

Limited research has been done concerning the role of prospective teachers' ability to use alternative structures (shared and guided reading and/or skills-focused lessons) to meet the needs of at-risk students in Trinidad and Tobago and the Caribbean., Review of the literature for the use of alternative structures, however produced many informative studies. Kosanovich describe complimentary lesson structures as the various activities that are implemented with students in a small group or one-one setting at teacher-led centres [17]. The researchers claim that it is critical for teachers to alter small group instruction based on the instructional needs of students, and recommend that teachers should increase their knowledge and proficiency using at least two types of alternative lesson structures - Guided Reading and Skills-Focused Lessons. The following routine was suggested by "What Works Clearing House", that: 1) provide training for teachers on how to collect and interpret student data on reading efficiently and reliably; provide training on how to use diagnostic measures, especially measures for those students experiencing difficulty, 2) develop data-driven decision rules for providing differentiated instruction to students at varied reading proficiency levels for part of the day and, 3) differentiate instruction - varying time, content, and degree of support and scaffolding - based on students' assessed needs.

\subsection{Assessment}

Research has shown that the primary concern in reading instruction should be the needs of each child, which can only be collected through assessment [24]. However, teachers must also be empowered to analyze the information from screening and diagnosis to obtain a better fit and match instruction with needs [13].

\subsection{Grouping}

After assessment data are analyzed, teachers must consider the grouping arrangements that will allow students to maximize their potential [13]. Ackrum states that it is best to employ a variety of grouping arrangements throughout the instructional block - during the whole group, all children can gain the needed exposure to curriculum-based, grade-level appropriate skills and strategies [1]. For whole group instruction, teachers can use shared reading or interactive read aloud to provide explicit teaching through modeling. However, whole group instruction will not meet the needs of all students in the class, so teachers are encouraged to differentiate instruction to engage students in various ways. Ackrum stresses that homogeneous, needs-based groups such as small-groups, peer groups, and one-one group should be formed based on the evidence provided by the diagnostic assessment [1].

\section{Adjusting/Managing the classroom environment}

One of the challenges identified in the literature is that of making adjustments to the classroom environment to allow teachers to teach small groups and at the same time, manage the independent groups in the class. Moody and Vaughn, reiterated that it is important for teachers to find methods to keep all children actively engaged in meaningful ways while meeting the needs of small groups or individual learners [19]. Schummn et al., in the National Reading Panel's report, stated that there are many methods available, however, teachers must choose the techniques to adjust and manage the learning environment that match their teaching style [21]. 


\subsection{Selecting Materials}

According to Ackrum, Allington, and Paperdue.com, materials chosen must match the reading level of the students in a small group. Teachers must use a variety of assessments for making their choices. The book selected and the instructional focus should support the development of reading skills and strategies needed by that particular group [1][4][21].

\subsection{Complimentary Structures}

Scholastic.com reported that guided reading is small-group reading instruction designed to provide differentiated instruction that supports students in developing reading proficiency at their instructional level [22]. The teacher uses a tightly structured framework that allows for the incorporation of many research-based approaches into a coordinated whole [10]. After systematic assessment is done to determine students' strengths and needs, students are grouped for efficient reading instruction. The teacher during guided reading lesson selects a text that students will be able to process successfully with instruction [10].

\section{Guided Reading}

Florida Center for Reading Research (FCRR) describes Skills-Focused Lessons are teacher-planned lessons that provide the opportunity for more systematic and explicit practice on a relatively small number of critical elements (e.g., unknown consonant digraphs, vowel teams, and r-controlled vowels.) [9]. Beck suggests that they would also provide an opportunity for sustained, systematic, and interesting "word work" so as to build fluency and confidence in the application of these skills to reading words [6]. These lessons could draw upon lesson formats and content from the core reading program to reinforce knowledge and skill that was only weakly learned when it was taught in the whole group format.

Beck further postulates that in order for skills-focused lessons to be successful they should be interactive, paced quickly and appropriately target critical skills for each reading group [5]. There is no one set format, however, these lessons should match and align with the results from the assessment tool used.

\subsection{Skills-Focused Lessons}

Florida Center for Reading Research (FCRR),
(N.D.) describes Skills-Focused Lessons are teacher-planned lessons that provide the opportunity for more systematic and explicit practice on a relatively small number of critical elements (e.g., unknown consonant digraphs, vowel teams, and r-controlled vowels.). Beck suggests that they would also provide an opportunity for sustained, systematic, and interesting "word work" so as to build fluency and confidence in the application of these skills to reading words. These lessons could draw upon lesson formats and content from the core reading program to reinforce knowledge and skill that was only weakly learned when it was taught in the whole group format [6].

Beck further postulates that in order for skills-focused lessons to be successful they should be interactive, paced quickly and appropriately target critical skills for each reading group. There is no one set format, however, these lessons should match and align with the results from the assessment tool used [5].

\section{Shared Reading}

Shared reading could offer rich instructional opportunities as teachers share in the workload while students access the text Burkins \& Croft [7] Shared reading includes elements of a read-aloud and guided reading, being most valuable for systematic and explicit demonstration opportunities with shared text. Holdaway explains that shared reading makes connections with students through shared feelings and experiences and that it is more than a lesson; rather, it becomes a shared event [14].

\section{Differentiating Reading Instruction}

Gibson states that the problem most teachers face when differentiating instruction is 'how to' get everything done and increase student achievement. As stated, there is no explicit guide to systematic and explicit instruction in delivering differentiated instruction. In fact, it is reported that scientific research has not provided procedural models to differentiation, mainly because of the uncertainty surrounding what differentiation is and the limited research surrounding how to implement it in classrooms [13].

Even though there is no current standard step-by-step procedure to give teachers a guideline in order to differentiate reading instruction, the consensus in the literature is that the particulars of 'how-to' deliver that instruction should be left to the teacher, yet, there are core skills, which make up any differentiated reading instruction methodology. 
The researchers' position in this study was to give prospective teachers the core skills necessary to differentiate reading instruction, and evaluate the success of an individual teacher's reading instruction on the basis of fulfilling students' needs.

\section{Methodologies}

\subsection{Purpose of the Study}

The purpose of this study was to investigate whether training in diagnostic assessment and analysis; and alternative structures in reading provided to prospective teachers prior to their practicum assignments, will increase their ability to better meet the needs of students.

\subsection{Hypothesis}

The hypothesis for this study was as follows: Prospective teachers receiving systematic and explicit training in differentiated reading instruction assessment techniques and alternative structures will be better able to meet students' needs, at their reading level.

\subsection{Population and Sample}

The population for the study comprised all year-3 and year-4 teachers (in-service and pre-service) completing a Bachelor of Education degree in Special Needs, Early Childhood Care Education (ECCE) and Primary Education at the University of Trinidad and Tobago (UTT).

Participants for this study, 32 prospective teachers (30 females and two males), were purposively selected from a larger sample of 47 prospective teachers (44 females and three males). These participants registered for the courses Teaching English Language Arts II to Students With Mild to Moderate Disabilities, and Engaging In Classroom Practice/Enhancing and Improving Classroom Practices for Semester 2 and Teaching English Language Arts I to Students With Mild to Moderate Disabilities and Deepening the Field Teaching Experience for Semester 1. Selection criteria for these participants required that they participated in a prior study on differentiating instruction varying content, process and product to meet the needs of their students [16].

\subsection{Research Site}

This study was conducted in nine (9) of 537 primary schools in Trinidad and Tobago. The nine primary school sites were assigned on a quota-sampling basis and contained eight 'inclusive' schools (students with/without mild to moderate exceptionalities) and one of the 16 special schools. The assignment was representative of the population of failing ( $<50 \%$ of the students meeting benchmark on the Reading Comprehension subtest of the National Test) and passing schools ( $\geq 50 \%$ of the students meeting benchmark on the Reading Comprehension subtest). The site included nine (9) principals, thirty-two (32) directing teachers, one hundred and twenty-four (124) students in thirty-two (32) targeted primary classes from Infants One to Standard Three (See Table 2).

\section{Table 2: School Assignment for Sample Group}

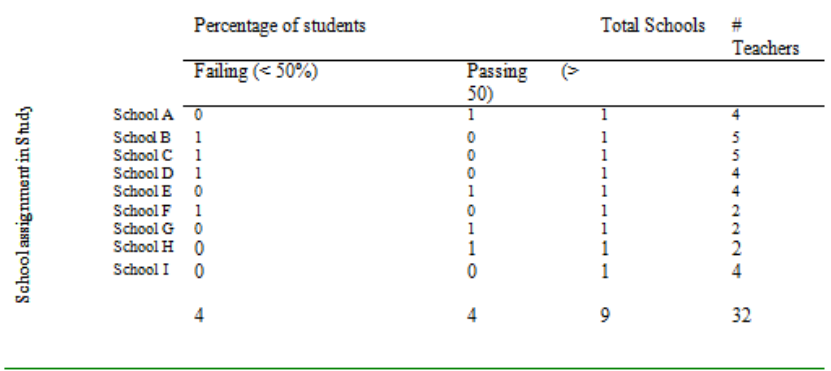

\subsection{Design}

The researchers set out to support or refute the hypothesis, and answer the aforementioned questions, by utilizing a convergent, mixed-method design that triangulates teacher reflections and survey responses with a single-group, pretest-posttest, quasi-experiment.

The dependent variable in this study was prospective teachers' ability to meet student needs in reading, operationalized by three student scores in prospective teacher performance obtained from presentations/demonstration, ongoing preparation, and examined field teaching; triangulated with data from prospective teacher perceptions of themselves shown in surveys and reflection notes.

i. Presentation/demonstration The lecturer in practice assessed prospective teachers ability to choose, create, modify and use appropriate resources to match curriculum content being delivered in classrooms based on the choice of a teaching strategy to be demonstrated in front of peers; the ability to discuss how and why the strategy was useful, and the ability to provide justification that it was the best decision in the circumstances for meeting the needs of their children. This assessment was evaluated using the Demonstration of an Instructional Strategy Rubric, adapted from UTT Practicum course content. See 
Table 3 below.

\section{Table 3: Rubric assessing presentation/ demonstration.}

Outstanding The prospective teacher consistently
[4]
the criteria and surpasses the
knowledge, skills, disposition and/or
performance skills of an initial
educator

Proficient The prospective teacher adequately [3] [2]

$\begin{array}{ll}\text { Beginning } & \text { The prospective } \\ \text { [1] } & \begin{array}{r}\text { teacher } \\ \text { limited }\end{array} \\ & \text { accomplishment of the criteria. } \\ & \text { There is much room for improvement } \\ & \text { on the knowledge, skills, disposition } \\ & \text { and/or performance skills of an initial } \\ & \text { educator. }\end{array}$

OBSERVED demonstrates some accomplishment of the criteria and meets the knowledge, skills, disposition and/or performance skills of an initial educator

Relevance of the strategy

- to lesson/context in which it is used

- to subject area

- to learners' level and abilities
- theoretical underpinnings:

Differentiated instruction

Suitability of explanation re: use in delivery

- Diction / clarity of speaker

- Content presented: name of strategy, purpose, targeted learners characteristics; construction; other uses

- Time period for presentation maximized

- Benefits and challenges

Creativity re design of the strategy

- Originality of ideas used/ Innovation

- Selection of materials used to create resource

- $\quad$ Repeatable design

Technical quality

- Visual/tactile stimulation; size of print.

- Durability (can be reused in other lessons on other occasions, other subject areas

- Can be used for classroom display (as a learning tool)

- Adaptability: can be used for teacher demonstration/student discovery and manipulation; with/without teacher supervision.

- Intricate details

Effectiveness/Overall impact

- $\quad$ Aesthetically pleasing; general visual impact 
- Comprehensiveness of presentation

ii. On-going preparation. Prospective teachers were expected to be fully prepared each day while on field teaching. All unit and lesson plans were submitted to and approved by the lecturers in practice before these lessons were taught. They were kept in binders and made available for scrutiny during field visits. The evaluation of this assignment was based on specific criteria identified in the on-going preparation rubric as shown in Table 4.

Table 4. Ongoing Preparation Rubric [15\%]

\begin{tabular}{lrrr}
\hline $\begin{array}{l}\text { challenging (e.g. } \\
\text { from questioning, }\end{array}$ & & \\
student work) and & & \\
focused on & & \\
achieving the & & & \\
learning objectives & & & \\
\hline LEARNER-CENTRED & 0 & 1 & Evidence \\
CLASSROOM & & 2 & \\
& 3 & \\
& 4 & \\
\hline
\end{tabular}

- The teacher demonstrates an understanding of individual student skills and

$13-\mathbf{1 5 \%} \quad$ Fully prepared for field-orientation and field-teacher visits. reflections well maintained in a Practicum Folder and at all times.

9 - $\quad$ 12\% Mostly prepared for field-orientation and field-teacher Records of teaching and reflections maintained in a Practicum Folder.

5 - 8\% Mostly unprepared for field-orientation. Records of teaching and reflections not readily available or are incomplete.

0-4\% Always unprepared for field-orientation and field-teaching visits Records of teach $\mathrm{g}$ and reflections not available.

iii. Examined field teaching. Prospective teachers planned, delivered, and were evaluated on lessons taught over the two-week period. On field-teaching days, each prospective teacher taught two (2) pre-planned lessons by him/herself while being observed by his/her cooperating teacher or lecturer in practice. The examination of this assignment was based on specific criteria identified in the differentiated instruction rubric in Table 5.

Table 5: tool B4: Differentiated Instruction Rubic(Chicago Public School, ND)

\begin{tabular}{llll}
\hline KNOWLEDGE-CENTRED & $\mathbf{0}$ & $\mathbf{1}$ & Evidence \\
CLASSROOM & $\mathbf{2}$ & $\mathbf{3}$ & \\
& $\mathbf{4}$ & & \\
\hline
\end{tabular}

- The lesson is based on clear objectives (based on learning goals and content standards) and all students are supported to meet those objectives

- Students are presented with tasks that are appropriately
- The teacher provides adequate time to gauge student prior knowledge.

- Students have sufficient time to meet the lesson objectives given different learner needs.

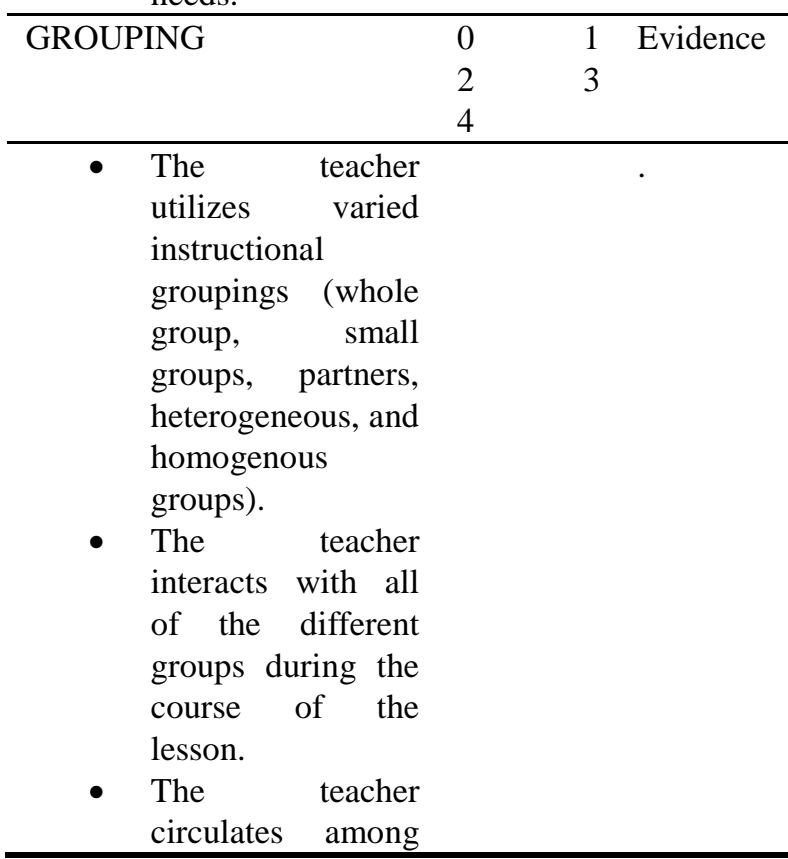




\begin{tabular}{|c|c|c|c|}
\hline $\begin{array}{l}\text { the groups to } \\
\text { ensure students are } \\
\text { learning and } \\
\text { provide feedback }\end{array}$ & & & \\
\hline MATERIALS & $\begin{array}{l}0 \\
2 \\
4\end{array}$ & $\begin{array}{l}1 \\
3\end{array}$ & Evidence \\
\hline $\begin{array}{l}\text { The materials in } \\
\text { the classroom } \\
\text { environment allow } \\
\text { for all learner } \\
\text { needs ai.e. } \\
\text { materials at } \\
\text { different levels, } \\
\text { allow for multiple } \\
\text { learning styles. } \\
\text { The materials are } \\
\text { accessible by } \\
\text { students }\end{array}$ & & & \\
\hline $\begin{array}{l}\text { PROACTIVE PLANNING } \\
\text { AND INSTRUCTION }\end{array}$ & $\begin{array}{l}0 \\
2 \\
4\end{array}$ & $\begin{array}{l}1 \\
3\end{array}$ & Evidence \\
\hline $\begin{array}{l}\text { - The lesson plan } \\
\text { reflects potential } \\
\text { struggles students } \\
\text { may have with } \\
\text { content } \\
\text { The lesson is } \\
\text { differentiated on } \\
\text { one or more of the } \\
\text { following } \\
\text { variables: content, } \\
\text { product, process }\end{array}$ & & & \\
\hline CONTENT & $\begin{array}{l}0 \\
2 \\
4\end{array}$ & $\begin{array}{l}1 \\
3\end{array}$ & Evidence \\
\hline $\begin{array}{l}\text { - } \text { The teacher has } \\
\text { prioritized what } \\
\text { content students } \\
\text { are expected to } \\
\text { learn (e.g. essential } \\
\text { material vs. } \\
\text { incidental } \\
\text { facts/enrichment) }\end{array}$ & & & \\
\hline PROCESS & $\begin{array}{l}0 \\
2 \\
4\end{array}$ & $\begin{array}{l}1 \\
3\end{array}$ & Evidence \\
\hline 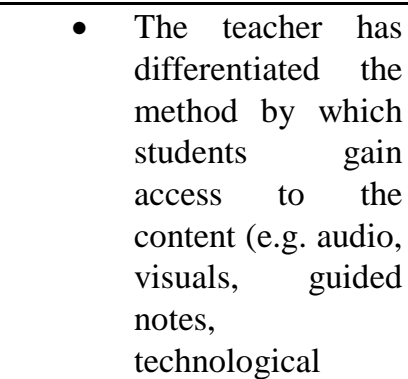 & & & \\
\hline
\end{tabular}

\begin{tabular}{|c|c|c|}
\hline $\begin{array}{l}\text { assistance) } \\
\text { - The teacher has } \\
\text { planned for } \\
\text { different activities } \\
\text { by which student } \\
\text { can engage in or } \\
\text { make sense of the } \\
\text { content (based on } \\
\text { student interest, } \\
\text { need, learning } \\
\text { style, etc.) }\end{array}$ & & \\
\hline PRODUCT & $\begin{array}{l}0 \\
2 \\
4\end{array}$ & $\begin{array}{ll}1 & \text { Evidence } \\
3 & \end{array}$ \\
\hline $\begin{array}{lr}\text { - } & \text { The teacher has } \\
\text { planned various } \\
\text { performance } \\
\text { indicators for } \\
\text { students to } \\
\text { demonstrate } \\
\text { evidence of } \\
\text { learning (tiered } \\
\begin{array}{l}\text { assessments, } \\
\text { choice } \\
\text { culminating } \\
\text { products ) }\end{array} \\
\end{array}$ & & \\
\hline
\end{tabular}

\subsection{Independent variable}

The independent variable was differentiated instruction training in diagnostic reading assessment and analysis, and systematic training in guided and shared reading and skills-focused lessons. In the pretest no instruction was given to prospective teachers in differentiating reading instruction, that is, systematic training was not conducted in diagnostic assessment and analysis, shared and guided reading or skills-focused lessons. 


\subsection{Intervention}

The independent variable was differentiated instruction training in diagnostic reading assessment and analysis, and systematic training in guided and shared reading and skills-focused lessons. In the pretest no instruction was given to prospective teachers in differentiating reading instruction, that is, systematic training was not conducted in diagnostic assessment and analysis, shared and guided reading or skills-focused lessons.

i. $\quad$ Procedure. A schedule of training in 'how to' differentiate reading instruction was arranged See Table 6.

Table 6: Training schedule for prospective teachers

\begin{tabular}{lllllllllllll}
\hline Cou & W & W & W & W & W & W & W & W & W & W & W & W \\
rses & 1 & 2 & 3 & 4 & 5 & 6 & 7 & 8 & 9 & 1 & 1 & 1 \\
& & & & & & & & & & 0 & 1 & 2
\end{tabular}

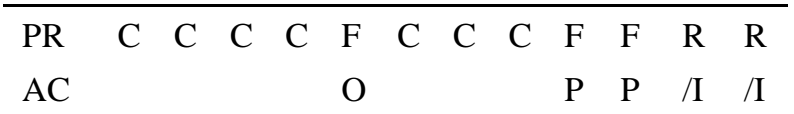

300

2

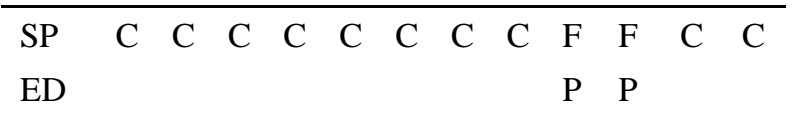

300

6

$\mathrm{W}=$ Week, $\mathrm{C}=$ Classroom sessions, FTP $=$ Field Teaching Practice, $\mathrm{R} / \mathrm{I}=$ Reflection/Instruction

ii. Module 1:Assessment and analysis of data. Hands-on training was conducted in the assessment, and analyzing of test data using Ekwall/Shanker Reading Inventory (ESRI) [23]. According to Shanker \& Cockrum, the ESRI is a set of test instruments designed for the assessment or diagnosis of individual students' reading abilities. These tests reveal each student's performance data on all critical reading skills.

iii. Module 2: Management of the learning environment. Prospective teachers were given direct, explicit instruction on how to adjust/manage the learning environment, transitioning from whole group instruction to small groups - some independently run, others teacher-led.

iv. Module 3: Unit and lesson planning. Training included systematic instruction in preparing unit and lesson plans that utilize alternative structures. Table 6 illustrates the plan of training over a twelve-week period. All unit/lesson plans for the Field Teaching Practice (FTP) assignment prepared were handed in to the lecturer in practice on week 7 (W7) initial draft and week 8 (W8) final draft of the training plan. The final draft of the unit was based on approval/editing discussions between lecturers in practice and prospective teachers.

For each of the two FTP weeks, each prospective teacher designed one unit of work for English Language Arts (ELA) to be covered in five lessons - shared reading, and five guided reading or skills-focused lessons per week, two for each of the different instructional level groups in the assigned class.

\section{Results}

Training prospective teachers to use a diagnostic reading assessment tool to determine the need areas of the students that facilitate formulation of group structures for small group instruction, significantly improved their performance on three dependent variables. A paired-sample t-test compared systematic training for prospective teachers in differentiating reading instruction in Semester II with no training conditions in Semester I. For each independent variable, with 99\% confidence, the null hypothesis (mean differences were equal to zero) was rejected. These findings support the researchers' hypothesis that explicit training in assessment strategies, and alternative structures in reading will positively affect prospective teachers ability to meet students' needs (See Table 7).

Table 2: Paired t-test for prospective teachers scores before - Semester 1, after Semester II

\begin{tabular}{|c|c|c|c|c|c|c|}
\hline Variables & $N$ & $\begin{array}{l}\mathrm{D} \\
\mathrm{F}\end{array}$ & $\mathrm{T}$ & $\begin{array}{l}\mathrm{P} \\
\text { value }\end{array}$ & $\begin{array}{l}\text { Mean } \\
\text { of } \\
\text { Diffe } \\
\text { rence }\end{array}$ & \\
\hline $\begin{array}{l}\text { presentation } \\
\text { S/ } \\
\text { demonstrati } \\
\text { ons }\end{array}$ & $\begin{array}{l}2 \\
9\end{array}$ & $\begin{array}{l}2 \\
8\end{array}$ & $\begin{array}{l}-7 . \\
48\end{array}$ & $\begin{array}{l}p \quad= \\
0.000 \\
00004\end{array}$ & -2.14 & $\begin{array}{l}\text { Alternative } \\
\text { hypothesis is } \\
\text { true, means } \\
\neq 0, p>.01\end{array}$ \\
\hline $\begin{array}{l}\text { On-going_pr } \\
\text { eparation }\end{array}$ & $\begin{array}{l}2 \\
9\end{array}$ & $\begin{array}{l}2 \\
8\end{array}$ & $\begin{array}{l}-2 \\
86\end{array}$ & $\begin{array}{l}p \quad= \\
0.007 \\
964\end{array}$ & -1.73 & $\begin{array}{l}\text { Alternative } \\
\text { hypothesis is } \\
\text { true, means } \\
\neq 0, p>.01\end{array}$ \\
\hline $\begin{array}{l}\text { field_teachi } \\
\text { ng_practice }\end{array}$ & $\begin{array}{l}2 \\
9\end{array}$ & $\begin{array}{l}2 \\
8\end{array}$ & $\begin{array}{l}-4 . \\
25\end{array}$ & $\begin{array}{l}P \quad= \\
0.000 \\
2154\end{array}$ & -7.76 & $\begin{array}{l}\text { Alternative } \\
\text { hypothesis is } \\
\text { true, means } \\
\neq 0, p>.01\end{array}$ \\
\hline
\end{tabular}

The quantitative data analysis was triangulated with the qualitative data gathered from a survey instrument and the prospective teachers' reflections. 
The results showed that prospective teachers followed the procedural guidelines given during training and they were able to administer and use diagnostic reading assessment to determine students' needs, form semi-permanent groups by homogenous instructional levels, and carefully select matched instructional materials to deliver alternative lesson structures.

As shown in Table 8, prospective teachers perceived that they met the needs of students in their growth of vocabulary, comprehension and understanding; relevant instructional material; skills-focused development; and in addressing personal weaknesses.

\section{Table 3: How prospective teachers perceived that needs were met during Guided reading}

\begin{tabular}{|c|c|c|}
\hline Perceived Needs Met & $\begin{array}{l}\text { No. } \\
\text { Participants }\end{array}$ & Percent \\
\hline Growth in vocabulary & 28 & $96 \%$ \\
\hline $\begin{array}{l}\text { Comprehension } \\
\text { Understanding }\end{array}$ & 29 & $100 \%$ \\
\hline $\begin{array}{l}\text { Relevant Instructional } \\
\text { Material }\end{array}$ & 28 & $96 \%$ \\
\hline Various Skill Development & 28 & $96 \%$ \\
\hline $\begin{array}{l}\text { Addressing } \\
\text { Weaknesses }\end{array}$ & 4 & $14 \%$ \\
\hline
\end{tabular}

Ninety-nine percent of the prospective teachers perceived that they met the needs of their students while teaching guided reading lessons. Fourteen percent of the prospective teachers, who were in remedial classes and at one of the special schools, had students that they instructed at different spectra of emergent reading; used skills-focused lessons; and felt that they addressed the students' pre-assessed weaknesses.

Table 9 illustrates the challenges experienced by prospective teachers.

The quantitative data analysis was triangulated with the qualitative data gathered from a survey instrument and the prospective teachers' reflections. The results showed that prospective teachers followed the procedural guidelines given during training and they were able to administer and use diagnostic reading assessment to determine students' needs, form semi-permanent groups by homogenous instructional levels, and carefully select matched instructional materials to deliver alternative lesson structures.
Table 9: Challenges encountered during Guided Reading

\begin{tabular}{|c|c|c|}
\hline $\begin{array}{l}\text { Areas of } \\
\text { Challenge }\end{array}$ & Frequency & Percent \\
\hline Classroom & 18 & 62.2 \\
\hline \multicolumn{3}{|l|}{ Management } \\
\hline Pacing the & 1 & 3.4 \\
\hline \multicolumn{3}{|l|}{ Lesson } \\
\hline Time & 5 & 17.2 \\
\hline \multicolumn{3}{|l|}{ Management } \\
\hline Lack & \multirow[t]{2}{*}{5} & 17.2 \\
\hline resources & & \\
\hline Total & 29 & 100 \\
\hline \multicolumn{2}{|l|}{ Capturing Students' } & 13.7 \\
\hline \multicolumn{3}{|l|}{ Attention } \\
\hline \multicolumn{2}{|l|}{ Staying on Task } & 6.8 \\
\hline \multicolumn{2}{|l|}{ Time Management } & 20.7 \\
\hline \multicolumn{2}{|c|}{ Book was too small } & 3.4 \\
\hline \multicolumn{2}{|l|}{ Managing Various } & 3.4 \\
\hline \multicolumn{3}{|l|}{ Levels } \\
\hline \multicolumn{2}{|c|}{ Disruptive Students } & 6.8 \\
\hline \multicolumn{2}{|l|}{ Lack of Resources } & 3.4 \\
\hline $\begin{array}{l}\text { No challenges to } \\
\text { report }\end{array}$ & 12 & 41.4 \\
\hline
\end{tabular}

Total

$29 \quad 100$.

As shown in Table 8, prospective teachers perceived that they met the needs of students in their growth of vocabulary, comprehension and understanding; relevant instructional material; skills-focused development; and in addressing personal weaknesses

Sixty-two percent of the prospective-teachers experienced challenges of classroom management while instructing students at the teacher-led stations. Seventeen percent experienced challenges of time management and lack of resources, while three percent experienced challenges in the pacing of their shared and guided reading lessons.

Tables 10 and 11 are the original utterances of some of the prospective teachers during the practicum experience.\# 
Table 10: Reflections

"I particularly liked guided reading because I can focus on the diverse needs of the children and also work with some of them individually."

"Practicum 6 was an exhilarating experience! My greatest success came through a Reading breakthrough. After ESRI, I noticed that quite a few students were not at the grade instructional reading level, and were struggling within the classroom. By the time I had completed one shared and one guided reading lesson, students began to comment that they never knew Reading could be so much fun. I was able to see some growth in students, in the short period and was astonished to see that they began to make links with their reading to other subjects.

This was very emotional for me, since having previously taught, I had noticed that children on the whole could not read and comprehend, and it was hampering their performance in other subject areas. Seeing the reaction of my students to this "new way of reading" was truly rewarding.

In my opinion, Guided Reading should be conducted in schools on a daily basis, in a block period/form. This should be a mandatory part of our Year 4 practicum, since it was evidenced that the results are positive."

"This practicum I was assigned to the WP special school. The students vary in their disability however they were at the same instructional level, except they all had different skill need. I had five students to work with - one-nonverbal, one Down syndrome, two emotional behavioral disorders and one bipolar/hyperactive. Each student has an individual need therefore I needed to tailor my instructions to suit each child. On the first day, my field orientation day, I administered the ESRI to determine each student need. I prepared 20 differentiated lessons. I was required to do 10 shared and 10-guided reading lessons. The lessons were well planned and organized with the needs of the students in mind. I worked closely with my non-verbal student while giving my attention to the other students who needed my assistance. Pre-assessment was used for all the lessons to know students previous knowledge. I think all my lessons went well, since I met the needs of my students. My shared reading lesson was on Carnival, which the students enjoyed. One of my guided lessons with the group was about "The sandwich.” I used the reading strategy of sequencing and retelling. This lesson had a lot of student engagement and concrete evidence for students to relate to. Students were required to make a sandwich while recalling the sequential order of how to make a sandwich, recalling the facts from the book that they read. Time management was excellent!” 
Table 11: Examples of Reflections

from prospective teachers

Survey Items

2. How did you differentiate reading during this practicum?

3. How did you go about preparing your class for differentiated instruction in reading to meet their needs?

4. What procedure did you use to teach shared reading? List some steps.

7. What skills did you model?
Participants responses

Twenty-seven of the twenty-nine students said:

They used shared and guided reading.

Ninety percent of the prospective teachers said that they followed some of the procedures encountered during training.

nty-four of the twenty-nine participants listed the following steps:

1. Assess the children and discover their levels (instructional, independent and frustration)

2. Group them according to instructional level.

Model reading of the text

1) Prospective teachers navigate students through the book,

a) modeling and teaching the students concepts

b) models the knowledge/understandings that students will need.

c) uses the language needed and makes the lesson focus explicit.

2) Prospective teacher reads out loud/ students may take turns at reading the text with support and/or prompting. 


\section{Discussion}

Conducting training and giving continuous support to prospective teachers in implementing differentiated instruction to meet the needs of students during field teaching practice positively impacted their level of performance, empowering them to better meet the needs of the students that they taught. The majority of prospective teachers in the study felt that they were better able to meet the needs of the students during their field teaching practice while conducting their guided reading sessions. They felt that they were able to meet the needs of students by helping students develop reading comprehension skills. Some felt that it was the most effective tool to develop a student's primary reading skills,_and also to help the student develop higher-level comprehension skills. Prospective teachers were observed during guided reading instruction directly and explicitly helping students to establish fundamental skills necessary for proficient reading, strengthen specifically identified weaknesses, develop attention to detail, build fluency, and develop vocabulary knowledge. Most prospective teachers perceived that they had the ability to better meet students' needs and they emphasized that they would continue to use the information and experience gained in this study, in future practicum sessions. However, some prospective teachers felt that they needed strategies to manage the class during guided reading or skills-focused lessons with small groups. Others felt that they needed to pace the lessons more appropriately, especially in shared reading. Though managing small-group instruction has shown to be difficult for some62\% of the practicing teachers, while at the same time managing the independent groups in the classroom, 38\% perceived that their practicum was successful as they met the needs of students in various identified ways including managing and organizing the environment while all students were appropriately engaged. Most prospective teachers enjoyed engaging the students in shared reading lessons, since they blended with the new primary school's thematic, integrative curriculum (MOE, 2013). Many reported that it was easy to assign activities for independently led stations since they structured and organized the class so that their expectations were communicated and articulated to the children. During shared reading most prospective teachers conducted their instruction in a spirited manner, while others conducted it using a more structured approach. Whichever approach they chose, it made learning to read enjoyable for their students. Most of the prospective teachers reported that they provided their students with the opportunities to actively participate in reading. Their students learned to focus on the strategies of making predictions, and understood that illustrations can help create meaning. Students had opportunities to expand and develop new vocabulary, recognize letters and sounds in the context of the words of the story, understand concepts of the printed word, and use visual cues to aid them in the reading process.

\section{Limitations}

i. Access to the students at the respective sites. The short time span of the Field Teaching practice, as well as, the timing of the study limited the results of the study. Prospective teachers were on the field during the eleventh and twelfth weeks of a thirteen-week school term. Cooperating teachers were preparing their classes for end of term tests, and some schools were actively preparing for school and/or District Sports Meetings. Therefore, prospective teachers had little time to use a systematic approach to adjusting the learning environment to suit the teaching of differentiated lessons. While they were effective in the diagnosis of reading needs, and to some extent in matching instruction to needs, prospective teachers perceived that they needed more practice in managing the rest of the class during Guided Reading.

ii. Longitudinal effects. Most experimental studies are spread over a long time. In this case, the 
time from pretest to posttest was fifteen (15) weeks. The time available to investigate the research problem and to measure change within the sample was constrained by the duration of the assignment. The researchers were not able to control the length of the practicum, since the decision for the length of the study is subject to MOE timetable and the UTT calendar. Shortness of time during this practicum also had an impact on prospective teachers' ability to appropriately manage the learning environment. Students need to learn skills to work independently during guided reading times. The study time was too short for some prospective teachers to get their students used to the rules of working independently. However, future practicums in the participants' year-four, which will be longer, will provide them with the opportunity to implement rules and provide their students with chances to work with a variety of classmates, without teacher assistance.

Based on the results of this study, further experimental research will be conducted with emphasis on classroom management of independent groups while the teacher conducts instruction in small groups with guided reading or skills-focused lessons, and time management during shared reading. Further research that will focus on the organization, behaviour management and development of engaging activities for students at the independent stations will continue to empower prospective teachers.

Practitioners may benefit from future research that tracks the same prospective teachers in their fourth year of the Bachelor of Education programme, as well as the establishment of quality assurance measures to ensure the training programme continues to be administered with fidelity. Also, future research could be done measuring the impact of differentiated reading instruction on student reading achievement.

\section{References}

[1] Ackrum, J. W. (2006). Differentiated reading instruction in one exemplary teacher's classroom: A case study. UMI Number 3250978. Ann Arbor, MI: ProQuest Information and Learning Company.

[2] Allen, J. (2000). Yellow brick roads: Shared and guided paths to independent reading 4-12. Portland, ME: Stenhouse Publishers.

[3] Allington, R. L. (2005). The other five "pillars" of effective reading instruction.Reading Today, 22(3).

[4] Allington, R. L. (2006). Research and the three tier model. Reading Today, 23(20).

[5] Beck, I.L., \& Beck, E. (2006) 1E. Making Sense of Phonics. The Guilford Press.

[6] Beck, I.L., \& Beck, E. (2013). 2E. Making Sense of Phonics. The Guilford Press.

[7] Burkins, J.M., \& Croft, M.M. (2010). Preventing misguided reading: New strategies for guided reading teachers Newark, DE: International Reading Association. Retrieved from http:// www.readwritethink.org.

[8] Chicago Public School. (ND). Tool B4: Differentiated Instruction Rubric. Retrieved from http://www.bronxbash.com.

[9] Differentiated reading instruction: small group alternative ...(n.d.). Retrieved from http://www.fcrr.org/asssessment/pdf/smallgroupalternativ elessonstructure.pdf.

[10] Fountas I., \& Pinnell G.S. (2010). Guided Reading Research Papers. Portsmouth, NH: Heinemann. 
[11] Fountas I., \& Pinnell, G.S. (1996). Guided reading: Good first teaching for all children. Portsouth,NH:

Heinemann Educational.

[12] Gamse, G.L., et al., (2008). Reading First Impact Study Final Report. Retrieved from http://ies.ed.gov/ncee/pdf/20094038_1.pdf.

[13] Gibson,V. \& Hasbrouck, J. (2008). Differentiated Instruction: Grouping for Success, McGraw-Hill Higher Education.

[14] Holdaway, D. (1972). Independence in reading: A handbook on individualized procedures. New York: Scholastic.

[15] Holdaway, D. (1979). The foundations of literacy. New York: Scholastic.

[16] Joseph, S.\& John, Y. (2014). Practicum Experiences of Prospective Teachers in Differentiating. Instruction. Advances in Social Sciences Research Journal. Vol. 1. No. 3. 25-34.

[17] Kosanovich, M., Ladinsky, K., Nelson, L., \&Torgesen, J. (2007). Differentiated Reading Instruction: Small Group Alternative Lesson Structures for All Students. Guidance Document for Florida "Reading First" Schools. Retrieved April 21st, 2014 from http://eric.ed.gov/.

[18] Ministry of Education, the Republic of Trinidad and Tobago, Primary Curriculum Guides (February, 2014).https://drive.google.com/a/moe.edu.tt/. [19] Moody, S. W. \& Vaughn, S. (1997). Instructional grouping for reading. Remedial and Special Education, 18, 347-356.

[19] Guided reading program. (n.d.). Retrieved from http://teacher.scholastic.com/products/guidedreading/pdfs /GR_Research_Paper_2010.pdf
[20] National Test, Ministry of Education, the Republic of Trinidad and Tobago, (n.d.). Retrieved from http://www.moe.gov.tt/student_exam_ntest.html.

[21] National Reading Panel(2000). Teaching children to read: An evidence-based assessment of the scientific research literature on reading and its implications for reading instruction Retrieved from http://www.nichd.nih.gov/publications/nrp/report.cfm.

[21] Reading Instruction remediation Essays 1-40 (n.d.). Retrieved from http://paperdue.com

[22] Robb, L. (2010). Assessment for differentiating reading instruction. Scholastic Inc.

[23] Shanker, J. L \& Cockrum, W. (2014).Ekwall/Shanker Reading Inventory. 6/E. Pearson.

[24] Taylor, B. M., Pearson, P. D., Clark, K. F., \& Walpole, S. (2000). Effective schoolsand accomplished teachers: Lessons about primary grade reading instruction in low-income schools. Elementary School Journal, 101, 121-164.

[25] Taylor, B. M., Peterson, D., Pearson, P., \& Rodriguez, M. C. (2002). Lookinginside classrooms: Reflecting on the 'how' as well as the 'what in effective instruction. Reading Teacher 56, 270-280.

[26] What Works Clearninghouse LD Online. (n.d.). Assisting Students Struggling with Reading: Response to Intervention and Multi-Tier Intervention in the Primary Grades. Retrieved from http://ies.ed.gov/ncee/wwc/pdf/ pg_021809.pdf). 